\title{
Understanding the Psychological Perspective of Political Trust in Indonesia Context
}

\author{
Indro Adinugroho* \\ *Faculty of Psychology, Universitas Katolik Indonesia Atma Jaya
}

\author{
Submitted 26 June 2020 Accepted 22 October 2020 Published 2 December 2021
}

\begin{abstract}
Political trust, conceptually understood as a trust in politics, refers to the positive expectation from the citizen that the government, as an institution leader, will deliver citizen's best interest through policies and regulations. Political trust is considered as one of the indicators that mark legitimation of existing government in addition to the result from election. Trust in politics is a fundamental element that can connect government and citizens for which benefit policies acceptance and avoid political conflict. The dynamic interaction between government and citizens is the most valuable aspect in democracy, of which the government, as the highest administrator, carries aspiration from the public. For Indonesia, a democratic country with its uniqueness in culture, it is crucial to investigate factors that might contribute as the dimensions of political trust. Such comprehensive understanding can inform the betterment of the democratic practices in Indonesia towards a more robust democracy. In this review study, the author analysed political trust from psychological perspective and proposes four basic dimensions to understand political trust from Indonesian perspective. These are cultural dimension, gender dimension, subjective preference dimension and performance dimension.
\end{abstract}

Keywords: culture; gender; government; political; trust

\section{Introduction}

Political trust (PT) has become the central concept for all democratic countries, including Indonesia. This argument is constructed based on the function of PT as one of the indicators that mark the legitimation of existing government, based on the evaluation from the people towards government (Levi et al., 2009). The concept of PT is varied across countries due to differences of the political system (Hooghe et al., 2012), value (Mauk, 2020), and political perception among citizens (Hooghe \& Marien, 2013). For example, a group of African-American who live in USA tends to see prejudice, discrimination and economic deprivation as the important element for them to evaluate the performance of existing government (Mangum, 2016). On another view, a study conducted by Wong et al. (2011) in six Asian countries, China, Hong Kong, Singapore, Taiwan, South Korea and Japan using Asia Barometer Survey shows that political performance and economic condition as two crucial aspects.These two examples above show that different society have different perspective and understanding as their reference to forming political trust. The existence of PT in democratic

*Address for correspondence: indro.adinugroho@atmajaya.ac.id 


\section{Adinugroho || Understanding the Psychological Perspective}

countries must be considered as the important element underlying the relationship between citizens and institutions. In democracy, citizens hold the highest authority, and the government administers the country to deliver welfare and prosperity through politics, as the instrument (Munck, 2014). I argue that PT is the crucial element that connects citizens and government, which can be the indicator to evaluate the performance of one existing government.

PT is an empirical concept which indicates political legitimacy from people toward the government, indicating the degree of people's support to the Government. The concept of PT derived from the general concept of trust, which refers to a firm belief that indicates reliability, truth or ability on someone or something (Choi \& Woo, 2016; Ma \& Yang, 2014; Schiffman et al., 2010)). In this article, I define PT as a belief towards a political object (governmental institution) or subject (politician or candidate) to bring specific expected outcomes to enhance the nation, such as qualified policies, economic improvement and social welfare.

At a macro level, PT can be viewed from two perspectives, institutional (Rothstein \& Stolle, 2008) and cultural (Mishler \& Rose, 2001) theories. In institutional theory, PT is formed by the performance of the existing government. Institutional or organizational trust occurs when the response towards the government is positive. For example, positive feedback or response of citizens towards Government programs, i.e. tax reduction or social security programs for all citizens. On the contrary, distrust is a consequence when the public reaction turns negative. Cultural theory defines PT as the consequence of interpersonal trust and dynamic social context that is understood by individuals and/or groups. An explanation from this can be seen from some existing groups in Indonesia who utilize cultural norms, such as religion and tribes, as the source of perspective in seeing political leaders.

Although many theories have attempted to define PT and its dimensions, the basic concept of PT cannot be drawn cross-culturally. Different country and society will form different values, for which might affect the understanding and ideology towards politics. This statement is also relevant to Indonesia as a comparatively a young democratic country with different democratic culture compared to other countries, whether it is developed or developing countries. Indonesia has its own perception in defining and trusting politics as an instrument of change. Example for this can be seen from the argument stated by Dwiyanto (2013) in his book, "Mengembalikan Kepercayaan Publik Melalui Reformasi Birokrasi". He clearly states that the complexity of bureaucracy in Indonesia is the biggest challenge that should be solved immediately to gain public trust. Complexity and flawed in public services, such as corruption and bribery, are two factors that form the culture of politics in Indonesia. This argument that culture is the significant aspect in shaping the PT among citizens in democratic country is supported through the study by Choi and Woo (2016) who utilized the data from Asia barometer survey. Result shows that participant, Asian citizen, mostly rely on government performance in managing national economy as the reference to put their trust towards government institution.

Considering the crucial importance of PT to inform the betterment of the quality of democracy in Indonesia, further scrutiny to examine behavioral dimensions of PT in Indonesia's context is much needed. In this study, literature review will be focused on two perspectives: (1) socio-cultural perspective (e.g., religion, ethnicities, gender role and identity), and (2) political issues (e.g., corruption 


\section{Adinugroho || Understanding the Psychological Perspective}

and scandal). The study will critically examine scholarly sources such as journals and books as the empirical references for developing behavioral dimensions, and available standard measurement model/tool to understand construct of PT. Additionally, this study will also consider various studies which explain PT from various countries such as Netherlands (Denters, 2002; Van der Meer \& Zmerli, 2017) United States of America (Anderson \& LoTempio, 2002); Africa (Hutchison, 2011), and Asian countries (Wang, 2015).

\section{The Basic Concept of Interpersonal Trust, Trustworthiness and Distrust}

Conceptually, trust can be seen as a multi-disciplinary variable, which has been utilized to examine various disciplinary contexts, such as business (Pirson et al., 2016) and politics (Fernandez et al., 2016). Scholars who have studied trust refer to three fundamental elements, trustor, trustee and trust objects that determine the quality of trust relationship between trustor and trustee. Trust relationship is an interpersonal relationship that can be affected by various variables such as past experience (Chen et al., 2010); communication (Breetz et al., 2005) and reputation from the trustee (Lucas, 2005). Interpersonal trust in psychology refers to the psychological situation that can be dramatically shifted when the trust object is being changed by one or both parties (trustor and trustee). This shift will lead to other behavioral consequences that involve rational thinking and emotional response, such as avoiding cooperation if the negative experience exists between the two. However, due to the nature of this variable as the state condition, trust as a relationship can also be repaired, for example through forgiveness and apology (Leunissen et al., 2012) as the psychological response. Therefore, based on this logical understanding, Rotter (1980), Rotter (1967) defines interpersonal trust as the general expectancy held by an individual that the word, promise, oral or written statement of another individual or group can be relied upon.

Based on the empirical explanation from Rotter's framework, the concept of interpersonal trust has been utilized by many scholars to understand various psychological phenomena, particularly events that encourage mutual relationship between parties, can be between individual, individual and group, and between groups relationship. The quality of the relationship will determine the degree of trust between two or more parties, and when this situation occurs there will be other behavioral consequences. When trust is maintained with positive ambience, it can lead to the situation named as trustworthy, a perception from the trustee that the trustee is reliable enough after several events that involved trust as a mediator variable in their relationship. On the contrary, when trust is misunderstood, it will lead to distrust, a condition that occurs in trustor due to negative events that affect trust object and the reliability of trustee (Hawley, 2012). From this conception, trust as the variable that emerges in interpersonal relationships needs a psychological maintenance from both parties before it can moderate positive behaviors such as cooperation or teamwork (Guth et al., 1997), otherwise trust can be a backfire for both parties.

The maintenance process of trust as the variable will affect how both parties think and evaluate the relationship. Trust as an underlying variable in human relationships is related to how humans process information through low-effort thinking or controlled processes (Wyer Jr \& Srull, 2018) and 


\section{Adinugroho || Understanding the Psychological Perspective}

risk-taking behavior. Risk-taking can be defined as the decision to follow up risk as the primary consequences for the behavior in the future. Risk-taking as a human decision is often studied in management and business which involves financial relationship between two parties (i.e., investment). Based on the review from Theiss-Morse and Barton (2017), cognition plays an important role in evaluating and finally making decisions on the quality of trust between parties. Human cognition is also important to determine the connection between trust and risk-taking behavior where people with high intelligence often avoid risk by taking some rational considerations before forming the relationship. Thereby, it can be said that cognition as the mental process is determined by various variables, such as intelligence and education (Hooghe \& Marien, 2013). Low-effort thinking or intuition is one aspect that can be utilized in evaluating the situation before conducting a trust relationship which is categorized as low-effort thinking.

The importance of trust in human relationship can be found in various aspects such as increasing organizational performance (Oh, 2019; Salamon \& Robinson, 2008); reducing prejudice and encouraging cooperation (Dhont \& Van Hiel, 2011; Woolley \& Fishbach, 2017); business relationship (Franklin \& Marshall, 2019) up to improving the quality of democracy (Warren, 2017). Moreover, trust as psychological variable can also be affected situationally, such as through personality and trustworthiness (Furumo et al., 2009) and oxytocin (Declerck et al., 2020; Kosfeld et al., 2005). The process of how one forms trust towards others can be found in Figure 1, of which this relationship is possible to determine by two factors: internal factors such as level of cognition between two parties and external factors, such as reputation and social environment. These two factors can affect not only trustor and trustee, but also the quality of the trust object. The quality of relationship and perspective from trustor and trustee will lead to the logical consequences, trustworthy when the quality or being maintained is positive and distrust when the quality is negative between parties.

\section{Figure 1}

The psychological process for construction of trust

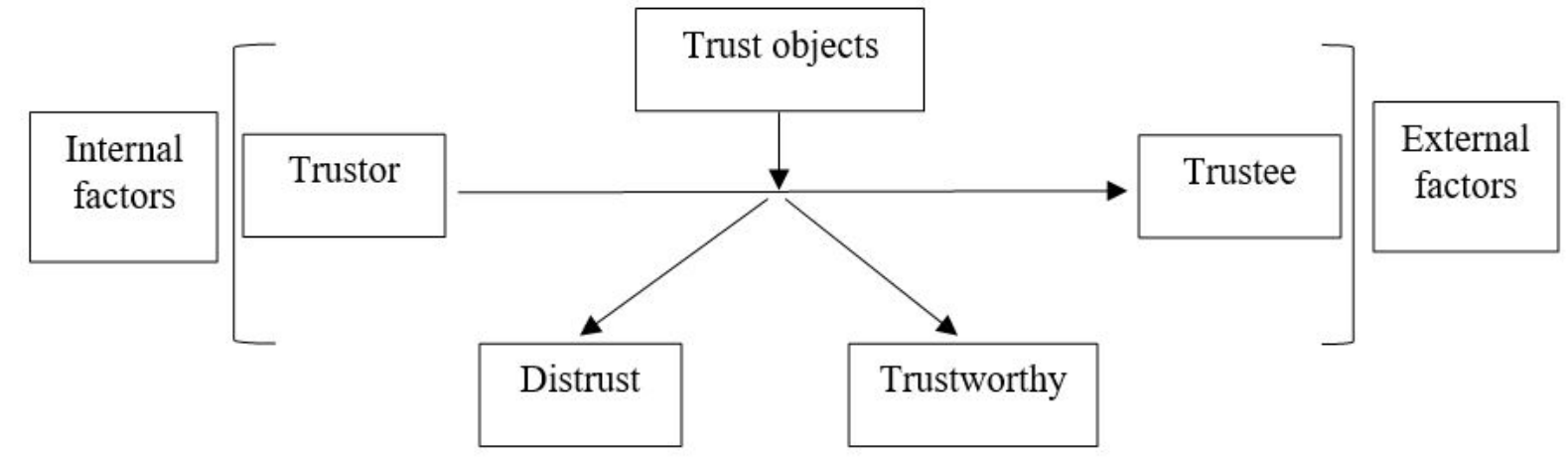

The concept of interpersonal trust was then expanded by many scholars to understand various situations that involve relationships between individual and institutional, named as institutional trust. This trust involves the relationship between individual and institution, as a group of people or 


\section{Adinugroho || Understanding the Psychological Perspective}

organization with vision and goal (Sonderskov \& Dinesen, 2015). The concept of institutional trust is constructed due to the need to understand the larger scale of human relationship in various aspects, such as human resource management (Shantz et al., 2017); politics (Godefroidt et al., 2016) and other macro issues to understand trust in bigger scale.

The existence of institutional trust is also considered important to reduce trust-cost possibly emerging when two parties have to make an agreement relying on specific issues (e.g., MOU or business agreement). In this context, trust-cost refers to psychological and financial cost when a trust relationship is not producing a positive outcome. In addition, institutional trust is also applied to understand the relationship between people and government named as PT. For example, a survey conducted by Hudson (2006) shows that institutional trust determines the degree of positive and negative well-being. This study involves a survey instrument named as Eurobarometer survey conducted across countries in European Union members. Result shows that when citizens tend to trust the European Central Bank, Government and the UN, it will bring a positive impact for citizen's well-being (Hudson, 2006).

\section{Organizational Trust: Understanding Trust in Politics}

PT as one form of trust relationship will involve different formats compared to trust in interpersonal relationships, which focus more on one-on-one relationships. However, relying on the concept of institutional or organizational trust, the basic concept to understand this relationship is equivalent. The difference between these concepts only refers to trust objects where organizational trust requires bigger scale, such as reputation of the organization or overall performance of the organization. Therefore, the consequences will also be bigger compared to interpersonal trust which only focuses on micro scale. Through institutional trust, democracy as the system can be established or industry can grow bigger to serve society through various products which finally can lead to the improvement in society. Organizational trust is also a relevant concept to be applied in democratic countries where connection between citizens and government is the main indicator to determine the quality of democracy applied in one country. Aside from that, the relationship between citizens and government is the object that needs to be maintained properly, particularly managing political events that is able to reduce the degree of trust between trustor and trustee, such as corruption issue (Wang, 2015).

\section{Ethnicity and Religions in Indonesian Politics}

As the biggest island country in the world, Indonesia consists of various cultural backgrounds that define subjective norms in each ethnic. For example, a study conducted by Sartini (2009) mentions that Javanese characteristics are related to humility, togetherness, and respect to the others, particularly to their parents, family and older person which is adopted in how Javanese speaks to others. Different from Javanese culture that focuses on humility, Bataknese, one of the ethnic who originate from Sumatra tend to raise their voice when they speak to others. However, this behavior cannot be considered as aggressive, but more related as the habit that is taught for years from generation to generation (Nugroho et al., 2012). These two cases are just the simple illustration to describe the richness of 


\section{Adinugroho || Understanding the Psychological Perspective}

Indonesian culture and this diversity also brought norms and perspective in how Indonesian citizens commit to their economic, social and political activities that can deliver meaning for themselves and their groups. Based on this cultural consideration, it can be suggested that each island in Indonesia does have a unique point of view in how they see politics for their life and also how to commit to decide their political leader to be trusted. Thereby, cultural uniqueness, diversity and demographic situation of Indonesia may lead this country to decide decentralization and independent autonomy as the applied governance system since 1999. The consequence of this decision is providing regional governments the rights to allocate and utilize their own budget and conduct regional elections.

The importance of ethnicity in politics for Indonesia should obtain extraordinary attention from various shareholders. We need to realize that ethnicities mostly affect the democratic system and how people form trust towards political actors. Examples for this argument can be seen across regions in Indonesia where every territory has its own perception and understanding of who can become a political leader. Thus, the concept of power-sharing can be seen as the concept which was constructed through domination of the majority towards the minority. Aside from that, cultural diversity also plays an important role in affecting how groups preserve their rights in elections. The Noken system that was established in Papua, Irian Jaya, the most eastern territory in Indonesia, became the system that needed to be preserved to maintain social and political stability in Papua. Noken refers to the system where aspirations are carried out by the chief of tribes through an acclamation system (Ronsumbre, 2019). This system is constructed by considering the identity of the chief of tribes as the leader of the group in various territories in Papua, Irian Jaya. After the aspiration sharing is finished, the chief will be responsible for carrying the aspiration to the provincial and national level from their group. Another perspective from the Noken system, indigenous groups named as Suku Anak Dalam in Jambi, Sumatera Indonesia acknowledge a different political system named as Jenang. This term actually refers to the representative of the tribe who obtains information including political information from the city and delivers it to the tribe (Idris et al., 2017). However, due to scarcity of information regarding the qualified candidates, most of the time, members of the tribe only follow the recommendation from the jenang as for their choice in election.

Two examples of Jenang and Noken might give the perspective of how cultural interaction delivers meaning in politics, particularly for indigenous groups. This meaning will definitely be affecting them in developing their perspective and make meaning as the reference to develop trust. Ethnicity and culture in Indonesia are mostly connected with adopted religion, for example religious majority in Bali (Hindu) is different from West Timor (Islam). The existence of various religious organizations who carry religious belief as the fundamental value in determining the quality of political leaders has become the trend that needs to be considered as well. For example, this case can be seen from the existence of Islamic Defenders Front (FPI) who always promote to choose Islamic leader for all Muslim as their requirement to get the blessing from Allah (Herawati, 2013). As the most populous Muslim country, Islam is often utilized by fundamentalist group as a political instrument for campaign and shifting public opinion. The case of Jakarta's Governor who is accused of insulting Islam through his speech (Atriana \& Mardiastuti, 2017) is the simple example of how easily religious belief 


\section{Adinugroho || Understanding the Psychological Perspective}

can be practically utilized in the public to change mindset and perspective of groups. Another example can be seen from different political competitions in Java and West Timor. While in East and West Java, Islam plays significant role in determining the quality of candidates, in West Timor the competition covers different religions, Catholic versus Christian groups (Mone, 2017). These cases point out that religion and religious belief that has been taught in Indonesian citizens since children are possible to become external factors that influence citizens in forming PT.

\section{Gender Role and Bias in Politics}

Ethnicities and religious belief are two elements in politics that often cannot be separately seen in a partial perspective. There is great potential for these elements to become significant predictors in affecting various political behaviors in Indonesia. One of the cultural outcomes which is produced from the interaction between ethnicities and religious belief is gender bias in politics. The problem of gender bias has occurred in Indonesia where parliament tends to be dominated by male groups since the last 15 years (Syafputri, 2017). There are many explanations in assessing how female group tend to avoid politics, including the examination from religious point of view where Islam as the dominant belief sometimes limit the activities of female in politics due to religious norms (Warjiyati, 2016). However, from the historical side, Islam does not teach to limit female to become the leader of the group in politics. Literature analysis conducted by Rofiq (2012) points out that female leader named Syajarat al-Durr became the most dominant woman in leading Islamist group in the crusades VII against Egypt. The movement to start criticizing gender bias in Islam is also conducted by Fatima Mernisi as the feminist activist in Morocco (Ghozali, 2014). She criticized some of the religious texts in the Quran and promoted historical facts that many of Islamic kingdoms were ruled by females. The historical facts were written in her great book, al-Sulthânât al-Mansiyât: Nisâ' Ra'îsât Dawlah fial-Islâm. Moreover, in Indonesia, the role of females in politics is also acknowledged to set up and make transformation, for example R. A Kartini who fought to break patriarchal culture by encouraging women to enter ducational institutions (Taylor, 1976).

Even though many studies had reviewed the issue of gender equality between male and female in Islam, the practice of gender bias is still emerging and becoming belief that affect public trust. Another possible explanation is the existence of patriarchal culture, the perspective in seeing male group is more dominant than the female in various occupations and roles as the leader and also knowledge (Omara, 2004). Patriarchal culture has been emerging across the world including in Indonesia. This case can be seen from various indicators, such as the establishment of National Commission on Violence against Women (Komnas Perempuan) as the national body in handling various social and political issues on females, such as domestic violence. This movement is the sign of care from the Indonesian government in seeing many violence cases that occur on female groups across islands, including the case that occurs due to patriarchal culture. Literature analysis conducted by Sakina et al. (2017) describes four indicators of social problems that are caused by the existence of patriarchal culture that mostly occur on female group who live in Indonesia, such as domestic violence, sexual harassment, early marriage and social stigma due to divorce. 


\section{Adinugroho || Understanding the Psychological Perspective}

The existence of patriarchal culture is a big challenge for Indonesia, and it affects how Indonesian citizens perceive social objects including religious meaning from sacred texts. Literature review conducted by Nurmila (2015) describes that patriarchal culture often affects people in perceiving religious belief from the Quran as the Islamic sacred texts. In her study, she reviewed how the perception of females as the second-class citizens under male often positioned as the incapable group and mostly positioned in domestic areas, such as the kitchen and taking care of children. Religious interpretation is possible to strengthen the perception of gender bias between male and female in various areas, including politics (Omara, 2004). Therefore, the existence of gender and representation of females are also important to consider and might affect the degree of PT between male and female groups toward government. In trust perspective, all of these social norms that are established in Indonesia are possible to contribute as external factors in affecting PT.

\section{Ideology and Personal Preference toward Political Candidate}

Politics in democratic country requires political party as the formal institution in carrying and expressing aspirations from numerous groups, such as Labor party or Islamist party in Europe who carry different ideologies in parliament which finally affecting the color of policies. By referring to the basic principle of democracy, it is clear that political parties should become the formal institutions in supporting the quality of democracy. Therefore, political parties should carry specific ideology to guide and direct them in the policy-making process. Besides that, a specific ideology carried out by a political party is the option for citizens that meet their expectations in building and setting direction for their country. Examples of strong ideologies can be seen from two big parties in the USA, Democrat with their liberalist perspective and Republic with their conservative thought. Difference in ideology between these two will affect how each party constructs policies in many areas such as tax, health, national defense and also economy (Conover \& Feldman, 1981; Hannikainen et al., 2017). For example, conservative tends to favor tax cut to support the economy and business, while Democrats tend to increase tax to support health and welfare programs for people (Rudolph, 2009), while for emotional conditions, conservative is seen as more easily disgusted than liberal (Inbar et al., 2009). As logical consequences, different ideology also affects the perception between these two ideologies in evaluating lesbian, gay and transgender issues. It is clear that conservaties tend to reject these practices while Democrats tend to support them in various aspects.

The concept of political ideology in the USA has been strongly embedded as the life pattern in the country, affecting behavior and their perspective, including how they put trust in the government. Through the existence of ideology, each group has a different signature in developing policies and even the existence of political ideology can also be seen to explore the characteristics of citizens. A study conducted by Jost et al. (2009) explores the relationship between personality and political ideology. By applying self-report instruments using Big Five personality as the framework to categorize personality profiles, research shows that openness to experience as the personality dimension is positively correlated with liberal perspective, while high degree of conscientiousness is positively correlated with conservative value. Personality as human trait in psychological perspective can be related 


\section{Adinugroho || Understanding the Psychological Perspective}

with trustworthiness, the characteristic which is mostly preserved as consistent in trust relationships (Hawley, 2012). By considering this result, demographic identification based on personality profile can be set up as an attempt to understand the characteristics of citizens across territories and can be utilized for various purposes such as intervention to reduce conflict or insight for policy-making.

Empirical studies from various fields have shown the importance of political ideology not only as a guide for citizens in the political process, but also for scholars to understand the larger population. However, the existence of clear political ideology in Indonesia is still in a grey area. Even though in Indonesia exists two dominant ideologies in politics, Islam and nationalist and represented by multi-party system, but the political execution based on that existing ideology is still dangling. This condition is represented with political coalitions that mostly occur in Indonesia and involve parties from different ideologies. Examples of this can be seen where parties with similar ideologies sometimes do not cooperate together in coalition to support the same candidates. Therefore, what is the most important ideology in Indonesia? Various studies have shown that popularity functions as a commodity in politics. Studies conducted by Choiriyati and Wiendijarti (2020) examined how the popularity of television actresses is the commodity that is mostly utilized by political parties to bolster their vote in elections. Liddle and Mujani (2007) in their study referred to this phenomena as the persona ideology (ideologi ketokohan), which refers to the perception that figure and popularity are two important elements to be acknowledged in politics and it is possible to affect PT.

\section{Transparency and Corruption Issues}

The dynamic of democracy which was established in Indonesia for over 20 years has produced various political behaviors in Indonesian society. Also, democracy in Indonesia has taught several norms and values for the public, for example how freedom of speech is guaranteed by Government to support the quality of Indonesia democracy (Poti, 2011) and transparency in budgeting and procedure are the common practice that must be conducted by the government in delivering outputs to the public (Gunawan, 2016; Hanifah \& Praptoyo, 2015). Freedom and transparency are two core elements which seem established in Indonesian democracy because it is related with corruption, a national and popular issue in Indonesian politics. As an attempt to establish transparency, the Indonesian government has already set up several practices where open data systems are acknowledged officially through national regulation for the public to be monitored (Wijayanto, 2015). It is the indicator of how this principle might affect citizens in trusting the government. One example of public distrust can be seen in the case of the Democrat party which is perceived as the most corrupt party in their second period as ruling party (2009 - 2014) leading to the failure in the 2014 election (Bomantama, 2018). This illustration sets up the argument that transparency and good governance practice are already perceived by Indonesian through corruption cases as the indicator to evaluate the performance of one government.

The issue of government performance is already addressed as one of the indicators in the Netherlands. Study which is conducted by Grimmelikhuijsen and Knies (2015) describes three fundamental behavioral dimensions in predicting trust towards government and one of the dimensions is related to perceived integrity, a belief to see honesty and fairness in how the government 


\section{Adinugroho || Understanding the Psychological Perspective}

works to deliver prosperity and public welfare. They also construct self-report instruments based on this framework through nine items with the scale ranges from 1 (totally disagree) to 5 (totally agree) and the issue of corruption and transparency are also addressed through these three dimensions, particularly in the perceived integrity aspect. In Indonesia, the role of Corruption Eradication Commission (KPK) as the independent body to prevent and fight corruption also shared valuable meanings in Indonesian politics, where a good government should obey the standard of transparency and anti-corruption while they act as political leaders. Therefore, it can also be seen that corruption that defines government performance is a possible dimension that shapes the degree of PT in Indonesia.

\section{Discussion}

Proposed Dimensions of Political Trust (PT)

PT as the central concept in psychology and politics is clearly cannot be seen as universal in all democratic countries. Two perspectives in political science which often applied to examine this variable are cultural perspective and institutional theories (Mishler \& Rose, 2001). The term cultural PT is a product of human trait that is influenced by many social and cultural situations, such as perspective, ethnicity, religion and other variables that might affect individual characteristic, while institutional refers to PT as the consequences of the existing governmental institutions that exist in democratic countries. Based on this theory, it can be explained why there is a difference of the concept of PT among democratic countries, for example between African-American and Hispanic are more concern on racism and discrimination issues in USA as the reference to generate trust towards. Study to investigate the trustworthiness aspects of political elites has been conducted by Haryanto et al. (2015). The study shows 10 factors that mostly can degrade the level of trust towards elites and two dominant issues are lie (29\%) and corruption (14\%). However, the examination of PT should be done comprehensively from various perspectives, not just psychological, but also cultural approach and macro environment. Therefore, in this study, the author considers three principles to understand the degree of PT in Indonesia, (1) people (2) culture and (3) political issues, particularly in Indonesia where the political situation is very dynamic and wide-ranging across islands. As an attempt to understand deeply on PT in Indonesian context, this paper proposes four behavioral dimensions which enables us to understand more comprehensive on PT;

1. Cultural dimension (ethnic \& religions) - This dimension will be related with norms and values which are derived from the existing ethnicities and religions. There are more than 200 ethnicities which emerged in Indonesia as the source of various norms \& values and these two elements might contribute to various perceptions in political settings, such as perceived political leadership and voting preference. Thus, as an attempt to measure the degree of PT among Indonesian, the evaluation of specific cultural dimensions should be addressed. This paper proposes three indicators consisting of religious belief, ethnic representation and cultural characteristics.

2. Gender dimension - Related to cultural dimension, gender is also intertwined with cultural 


\section{Adinugroho || Understanding the Psychological Perspective}

products. From its definition, I mention gender to explain gender role, social characteristic and public demands regarding the role of male and female in the society. In Indonesia, various study have shown that gender affects politics, particularly for female groups who often see themselves as minority in politics and perceive themselves as minority. Therefore, examination of male and female gender identity should be considered as well.

3. Subjective preference dimension - The reason why subjective preference is set as one of dimensions is derived from the logic that there is no strong and applied political ideology which exists in Indonesia. Even though many parties are said to carry specific ideology (e.g., nasionalist religius for Democrat party, Pancasila for Democratic Party or Islam for PKS and PPP), the political attitude and decision that made often inconsistent with their ideology. In the end, popularity and the role of figure are two primary principles that play roles in democracy and the tendency of candidates to get elected.

4. Performance dimension (transparency and corruption) - These two issues are considered due to the principle of democracy that has been established in Indonesia for more than 18 years. Historically, in 1998 - 1999, transparency and corruption are two primary issues that came up as the reason to replace Soeharto who had ruled for more than 30 years in Indonesia. These two terms were acknowledged as corruption, collusion and nepotism (KKN). Besides that, the role of National Corruption Eradication Commission (KPK) in Indonesia which was established under President Megawati is still needed until now as the response to control governance to abuse their power through corruption and gratification. The existence of this body can be said to share political meaning in society where politicians should avoid corruption and obey to the national standard.

\section{Conclusion}

Trust in politics is a fundamental factor, particularly for democratic countries, because it reflects the connection between government as the highest administrator and citizens as the highest stakeholder. Even though PT is mostly elaborated by political scientists, the existence of PT should be addressed more comprehensively from the perspective of psychology. This argument is based on an empirical assumption that trust is generated through a relationship between individuals and groups involving emotion, belief and perception, all of which are psychological processes. This argument is relevant to Indonesia, cultural diversity and the biggest island country in the world, of which behavioral dimensions that construct PT might be unique from those of other democratic countries. The study found four dimensions of PT, these are constructed based on the perspective of psychology, cultural and gender dimensions refer to perception of existing culture and social environment that might affect PT. Subjective preference is related to emotion which might be emerged by the appearance of a political leader. The last, performance dimension is related to the perception which might be constructed through cognitive process by evaluating the effectiveness of policies and regulations. 


\section{Adinugroho || Understanding the Psychological Perspective}

\section{Declarations}

Acknowledgement

Authors would like to express an enormous appreciation to Faculty of Psychology, Atma Jaya Catholic University of Indonesia as an institution which supported the logistics for the author to write and finalize the article. Especially for Atma Jaya Central Library to provide links and network to collect empirical and practical sources for the article.

\section{Funding}

This study was funded by the Center for Political and Human Behavior Studies under the Faculty of Psychology, Atma Jaya Catholic University of Indonesia.

\section{Author's contribution}

This study is written by single author who is responsible for literature review, data collection and writing all of the sections in the article.

\section{Conflict of Interest}

The authors declare that there is no conflict of interest in this research.

\section{Orcid ID}

Indro Adi Nugroho https:/ / orcid.org/0000-0002-8858-1908

\section{References}

Anderson, C. J., \& LoTempio, A. J. (2002). Winning, losing and political trust in america. British Journal of Political Science, 32(2), 335-351. http://www.jstor.org/stable/4092221

Atriana, R., \& Mardiastuti, A. (2017). Hakim: Ahok merendahkan surat al-maidah 51 [judge: Ahok degraded the al-maidah verse 51]. https : / / news . detik . com / berita / d - 3496149 / hakim - ahok merendahkan-surat-al-maidah-51

Bomantama, R. (2018). Ini tiga penyebab kekalahan partai demokrat di pilpres 2014 menurut ahy [these are the three causes of the loss of demokrat party in the presidential election 2014 according to ahy]. https: / / wartakota.tribunnews.com/2018/02/17/ini-tiga-penyebab-kekalahan-partai-demokratdi-pilpres-2014-menurut-ahy

Breetz, H. L., Fisher-Vanden, K., Jacobs, H., \& Schary, C. (2005). Trust and communication: Mechanisms for increasing farmers-participation in water quality trading. Land Economics, 81(2), 170-190. http://www.jstor.org/stable/4129663

Chen, Y.-H., Chien, S.-H., Wu, J.-J., \& Tsai, P.-Y. (2010). Impact of signals and experience on trust and trusting behavior. Cyberpsychology, Behavior, and Social Networking, 13(5), 539-546. https:/ / doi. org/10.1089/cyber.2009.0188 


\section{Adinugroho || Understanding the Psychological Perspective}

Choi, E., \& Woo, J. (2016). The origins of political trust in east asian democracies: Psychological, cultural, and institutional arguments. Japanese Journal of Political Science, 17(3), 410-426. https: //doi.org/10.1017/s1468109916000165

Choiriyati, W., \& Wiendijarti, I. (2020). Popularitas selebriti sebagai komoditas politik [celebrity popularity as political commodity]. Jurnal Ilmu Komunikasi, 9(2), 128-142. http://jurnal.upnyk. ac.id/index.php/komunikasi/article/view/3423

Conover, P. J., \& Feldman, S. (1981). The origins and meaning of liberal/conservative self-identifications. American Journal of Political Science, 617-645. https: / / doi.org / 10.2307 / 2110756

Declerck, C. H., Boone, C., Pauwels, L., Vogt, B., \& Fehr, E. (2020). A registered replication study on oxytocin and trust. Nature Human Behaviour, 4(6), 646-655. https: / / doi.org/10.1038/ s41562020-0878-x

Denters, B. (2002). Size and political trust: Evidence from denmark, the netherlands, norway, and the united kingdom. Environment and Planning C: Government and Policy, 20(6), 793-812. https: / / doi.org/10.1068/c0225

Dhont, K., \& Van Hiel, A. (2011). Direct contact and authoritarianism as moderators between extended contact and reduced prejudice: Lower threat and greater trust as mediators. Group Processes $\mathcal{E}$ Intergroup Relations, 14(2), 223-237. https:/ / doi.org/10.1177/1368430210391121

Dwiyanto, A. (2013). Mengembalikan kepercayaan publik melalui reformasi birokrasi [reviving public trust through reformation of burreaucracy]. Gramedia Pustaka Utama.

Fernandez, P. R., Kaur, S., Lean, M. L., \& Ng, K. H. (2016). Trust and politics in risk communication: Discourse analysis on radio frequency (rf) exposure in malaysia. Journal of Modern Languages, 26(1), 71-94. https://jati.um.edu.my/index.php/JML/article/view/2965

Franklin, D., \& Marshall, R. (2019). Adding co-creation as an antecedent condition leading to trust in business-to-business relationships. Industrial Marketing Management, 77, 170-181. https:/ / doi. org/10.1016/j.indmarman.2018.10.002

Furumo, K., de Pillis, E., \& Green, D. (2009). Personality influences trust differently in virtual and face-to-face teams. International Journal of Human Resources Development and Management, 9(1), 36-58. https:/ / www.inderscience.com/info/inarticle.php?artid=21554

Ghozali, A. M. (2014). Kepemimpinan politik wanita antara doktrin agama dan fakta sejarah (pemikiran fatima mernissi dalam al-sulthanat al-mansiyat) [women political leadership between religious doctrine and historical fact (the fatima mernissi school of thought in al-sulthanat al-mansiyat)]. Madania: Jurnal Kajian Keislaman, 18(2), 215-222. https: / / ejournal. iainbengkulu.ac.id/index.php/madania/article/view/17

Godefroidt, A., Langer, A., \& Meuleman, B. (2016). Developing political trust in a developing country: The impact of institutional and cultural factors on political trust in ghana. Democratization, 24(6), 906-928. https://doi.org/10.1080/13510347.2016.1248416 


\section{Adinugroho || Understanding the Psychological Perspective}

Grimmelikhuijsen, S., \& Knies, E. (2015). Validating a scale for citizen trust in government organizations. International Review of Administrative Sciences, 83(3), 583-601. https: / / doi.org/ 10.1177/0020852315585950

Gunawan, D. R. (2016). Penerapan sistem e-budgeting terhadap transparansi dan akuntabilitas keuangan publik (studi pada pemerintah kota surabaya) [the implementation effect of e-budgeting system towards the transparency and accountability of public finance (a study of surabaya city government)]. AKRUAL: Jurnal Akuntansi, 8(1), 72-102. https:/ / doi.org/10. 26740/jaj.v8n1.p72-102

Guth, W., Ockenfels, P., \& Wendel, M. (1997). Cooperation based on trust. an experimental investigation. Journal of Economic Psychology, 18(1), 15-43. https: / / doi.org / 10.1016/ s01674870(96)00045-1

Hanifah, S. I., \& Praptoyo, S. (2015). Akuntabilitas dan transparansi pertanggungjawaban anggaran pendapatan belanja desa (apbdes) [accountability and transparency of anggaran pendapatan belanja desa (apbdes)]. Jurnal Ilmu dan Riset Akuntansi (JIRA), 4(8). http: / / jurnalmahasiswa. stiesia.ac.id/index.php/jira/article/view/3584

Hannikainen, I. R., Miller, R. M., \& Cushman, F. A. (2017). Act versus impact: Conservatives and liberals exhibit different structural emphases in moral judgment. Ratio, 30(4), 462-493. https: //doi.org/10.1111/rati.12162

Haryanto, H. C., Rahmania, T., Mubarok, A. R., Dopo, A. B., Fauzi, H., \& Fajri, E. (2015). Bagaimanakah persepsi keterpercayaan masyarakat terhadap elit politik? [how is the public's trustworthiness perception towards political elites?] Jurnal Psikologi, 42(3), 243-258. https:/ / doi.org/10.22146/ jpsi.9913

Hawley, K. (2012). Trust, distrust and commitment, 48(1), 1-20. https:/ / doi.org/10.1111/nous.12000 Herawati, W. D. (2013). Budidaya padi [rice cultivation]. Javaliter.

Hooghe, M., \& Marien, S. (2013). A comparative analysis of the relation between political trust and forms of political participation in europe. European Societies, 15(1), 131-152. https: / doi.org / 10.1080/14616696.2012.692807

Hooghe, M., Marien, S., \& de Vroome, T. (2012). The cognitive basis of trust. the relation between education, cognitive ability, and generalized and political trust, 40(6), 604-613. https: / / doi. org/10.1016/j.intell.2012.08.006

Hudson, J. (2006). Institutional trust and subjective well-being across the eu. Kyklos, 59(1), 43-62. https: //doi.org/10.1111/j.1467-6435.2006.00319.x

Hutchison, M. L. (2011). Territorial threat and the decline of political trust in africa: A multilevel analysis. Polity, 43(4), 432-461. https://doi.org/10.1057/pol.2011.3

Idris, N. Et al. (2017). Mengkaji ulang pola komunikasi pemerintah dalam pemberdayaan suku anak dalam di provinsi jambi [re-analyzing government communication pattern in the empowerment of anak dalam tribe in jambi province]. Jurnal Penelitian Pers Dan Komunikasi Pembangunan, 21(1), 37-48. 


\section{Adinugroho || Understanding the Psychological Perspective}

Inbar, Y., Pizarro, D. A., \& Bloom, P. (2009). Conservatives are more easily disgusted than liberals. Cognition and emotion, 23(4), 714-725. https://doi.org/10.1080/02699930802110007

Jost, J. T., West, T. V., \& Gosling, S. D. (2009). Personality and ideology as determinants of candidate preferences and-obama conversion-in the 2008 us presidential election. Du Bois Review: Social Science Research on Race, 6(1), 103-124. https:/ / doi.org/10.1017/s1742058x09090109

Kosfeld, M., Heinrichs, M., Zak, P. J., Fischbacher, U., \& Fehr, E. (2005). Oxytocin increases trust in humans. Nature, 435(7042), 673-676. https://doi.org/10.1038/nature03701

Leunissen, J. M., De Cremer, D., \& Folmer, C. P. R. (2012). An instrumental perspective on apologizing in bargaining: The importance of forgiveness to apologize. Journal of Economic Psychology, 33(1), 215-222. https:/ /doi.org/10.1016/j.joep.2011.10.004

Levi, M., Sacks, A., \& Tyler, T. (2009). Conceptualizing legitimacy, measuring legitimating beliefs. American behavioral scientist, 53(3), 354-375. https://doi.org/10.1177/0002764209338797

Liddle, R. W., \& Mujani, S. (2007). Leadership, party, and religion: Explaining voting behavior in indonesia. Comparative Political Studies, 40(7), 832-857. https : / / doi . org / 10.1177 / 0010414006292113

Lucas, L. M. (2005). The impact of trust and reputation on the transfer of best practices. Journal of Knowledge Management. https:/ / doi.org/10.1108/13673270510610350

Ma, D., \& Yang, F. (2014). Authoritarian orientations and political trust in east asian societies. East Asia, 31(4), 323-341. https://doi.org/10.1007/s12140-014-9217-z

Mangum, M. (2016). Explaining political trust among african americans. Journal of Public Management E Social Policy, 23(2), 7. https://digitalscholarship.tsu.edu/jpmsp/vol23/iss2/7

Mauk, M. (2020). Disentangling an elusive relationship: How democratic value orientations affect political trust in different regimes. Political Research Quarterly, 73(2), 366-380. https: / / doi . org $/ 10.1177 / 1065912919829832$

Mishler, W., \& Rose, R. (2001). What are the origins of political trust? testing institutional and cultural theories in post-communist societies. Comparative political studies, 34(1), 30-62. https: / / doi. org/10.1177/0010414001034001002

Mone, A. (2017). Konsensus politik kristen vs katolik dalam pilgub ntt [christians vs catholics political consensus in governor election of $n t t]$. https: / / www. qureta.com / post / konsensus - politik kristen-vs-katolik-dalam-pilgub-ntt

Munck, G. L. (2014). What is democracy? a reconceptualization of the quality of democracy. Democratization, 23(1), 1-26. https://doi.org/10.1080/13510347.2014.918104

Nugroho, A. B., Lestari, P., \& Wiendijarti, I. (2012). Pola komunikasi antarbudaya batak dan jawa di yogyakarta [communication pattern between batak and javanese cultures in yogyakarta]. Jurnal Aspikom, 1(5), 403-418. https://doi.org/10.24329/aspikom.v1i5.44

Nurmila, N. (2015). Pengaruh budaya patriarki terhadap pemahaman agama dan pembentukan budaya [the influence of patriarchal culture towards religion understanding and culture formation]. KARSA: Journal of Social and Islamic Culture, 23(1), 1-16. https:/ / doi.org/10.19105/ karsa.v23i1.606 
Oh, S.-Y. (2019). Effects of organizational learning on performance: The moderating roles of trust in leaders and organizational justice. Journal of Knowledge Management, 23(2). https: / / www. emerald.com/insight/content/doi/10.1108/JKM-02-2018-0087/full/html

Omara, A. (2004). Perempuan, budaya patriarki dan representasi [women, patriarchal culture, and representation]. Mimbar Hukum, 2(2004). http:/ /i-lib.ugm.ac.id/jurnal/detail.php?dataId= 2625

Pirson, M., Martin, K., \& Parmar, B. (2016). Public trust in business and its determinants. Business $\mathcal{E}$ Society, 58(1), 132-166. https:/ / doi.org/10.1177/0007650316647950

Poti, J. (2011). Demokratisasi media massa dalam prinsip kebebasan [mass media democratization in freedom principle]. Jurnal Ilmu Politik dan Ilmu Pemerintahan, 1(1), 17-29. https: / fisip.umrah. ac.id/wp-content/uploads/2012/03/JURNAL-ILMU-PEMERINTAHAN-BARU-KOREKSIlast.23-35.pdf

Rofiq, A. C. (2012). Kontroversi kepemimpinan politik perempuan periode pertengahan: Kasus pemerintahan syajarat al-durr masa dinasti mamluk [controversion of women political leadership in the medieval age: The case of syajarat al-durr government in the mamluk dynasty]. Kodifikasia, 6(1), 1-23. https: / / jurnal.iainponorogo.ac.id/index.php/kodifikasia / article/view /763

Ronsumbre, N. (2019). Sistem noken papua: Manifestasi demokrasi berbasis kearifan lokal [noken papua system: Manifestation of local wisdom-based democracy]. Sospol: Jurnal Sosial Politik, 5(2), 261-276. https://doi.org/10.22219/sospol.v5i2.7388

Rothstein, B., \& Stolle, D. (2008). The state and social capital: An institutional theory of generalized trust. Comparative politics, 40(4), 441-459. https: / / doi.org/10.5129/001041508x12911362383354

Rotter, J. B. (1980). Interpersonal trust, trustworthiness, and gullibility. American Psychologist, 35(1). https:/ / doi.org/10.1037/0003-066X.35.1.1

Rotter, J. B. (1967). A new scale for the measurement of interpersonal trust. Journal of personality, 35(4). https://doi.org/10.1111/j.1467-6494.1967.tb01454.x

Rudolph, T. J. (2009). Political trust, ideology, and public support for tax cuts. Public Opinion Quarterly, 73(1), 144-158. https://doi.org/10.1093/poq/nfp012

Sakina, A. I. Et al. (2017). Menyoroti budaya patriarki di indonesia [highlighting patriarchal culture in indonesia]. Share: Social Work Journal, 7(1), 71-80. https:/ /jurnal.unpad.ac.id/share/article/ view $/ 13820 / 6628$

Salamon, S. D., \& Robinson, S. L. (2008). Trust that binds: The impact of collective felt trust on organizational performance. Journal of Applied Psychology, 93(3), 593-601. https: / / doi.org / 10.1037/0021-9010.93.3.593

Sartini, N. W. (2009). Menggali nilai kearifan lokal budaya jawa lewat ungkapan (bebasan, saloka, dan paribasa) [delving into the local wisdom value of javanese culture through idioms (bebasan, saloka, and paribasa)]. Jurnal ilmiah bahasa dan sastra, 5(1), 28-37. https:/ / repository.usu.ac.id/ bitstream/handle/123456789/17541/log-apr2009-5\%20(4).pdf;sequence=1 
Schiffman, L., Thelen, S. T., \& Sherman, E. (2010). Interpersonal and political trust: Modeling levels of citizens trust, 44(3/4), 369-381. https:/ / doi.org/10.1108/03090561011020471

Shantz, A., Wang, J., \& Malik, A. (2017). Disability status, individual variable pay, and pay satisfaction: Does relational and institutional trust make a difference? Human Resource Management, 57(1), 365-380. https://doi.org/10.1002/hrm.21845

Sonderskov, K. M., \& Dinesen, P. T. (2015). Trusting the state, trusting each other? the effect of institutional trust on social trust. Political Behavior, 38(1), 179-202. https:/ / doi.org/10.1007/ s11109-015-9322-8

Syafputri, E. (2017). Keterwakilan perempuan di parlemen: Komparasi indonesia dan korea selatan [woman representation in parliament: Comparison between indonesia and south korea]. Global South Review, 1(2), 165-176. https:/ / doi.org/10.22146/globalsouth.28839

Taylor, J. S. (1976). Raden ajeng kartini. Signs: Journal of Women in Culture and Society, 1(2), 639-661. http://www.jstor.org/stable/3173146

Theiss-Morse, E., \& Barton, D.-G. (2017). Emotion, cognition, and political trust. In Handbook on political trust. Edward Elgar Publishing.

Van der Meer, T. W., \& Zmerli, S. (2017). The deeply rooted concern with political trust. In Handbook on political trust. Edward Elgar Publishing. ttps:/ / hal.archives-ouvertes.fr/hal-01475618

Wang, C.-H. (2015). Government performance, corruption, and political trust in east asia. Social Science Quarterly, 97(2), 211-231. https://doi.org/10.1111/ssqu.12223

Warjiyati, S. (2016). Partisipasi politik perempuan perspektif hukum islam [women political participation in islamic law perspective]. Al-Daulah: Jurnal Hukum dan Perundangan Islam, 6(1), 1-27. https:/ / doi.org/10.15642/ad.2016.6.1.1-27

Warren, M. (2017). Trust and democracy (E. M. Uslaner, Ed.). Oxford University Press. https:/ /doi.org/ 10.1093/oxfordhb/9780190274801.013.5

Wijayanto, H. (2015). Transparansi anggaran pendapatan dan belanja daerah (apbd) melalui penerapan e-budgeting (dalam perspektif teori good governance) [transparency of regional income and outcome book (apbd) through the implementation of e-budgeting (in perspective of good governance theory)]. The Indonesian Journal of Public Administration (IJPA), 1(1), 72-88. https://doi.org/10.52447/ijpa.v1i1.79

Wong, T. K.-y., Wan, P.-s., \& Hsiao, H.-H. M. (2011). The bases of political trust in six asian societies: Institutional and cultural explanations compared. International Political Science Review, 32(3), 263-281. https:/ / doi.org/10.1177/0192512110378657

Woolley, K., \& Fishbach, A. (2017). A recipe for friendship: Similar food consumption promotes trust and cooperation. Journal of Consumer Psychology, 27(1), 1-10. https:// doi.org/10.1016/j.jcps. 2016.06.003

Wyer Jr, R. S., \& Srull, T. K. (2018). Advances in social cognition, volume i: A dual process model of impression formation. Psychology Press. https: / / www.routledge.com / Advances-in-Social-CognitionVolume-I-A-Dual-Process-Model-of-Impression/Wyer-Jr-Srull/p/book/9780898596731 